UDC 316.3:32.019.5

Astghik PETROSYAN

\title{
METHODOLOGICAL ANALYSIS OF POLITICAL PARTICIPATION INDICATOR EVALUATION TOOLS
}

\begin{abstract}
The article analyzes issues of political participation. The article discusses main stages and features of formation of the concept of political participation in sociology and political science. Definition of political participation is offered based on the analysis of the interpretations available in professional literature. Political participation is involvement of citizens (in the broader sense including public subjects like organizations, groups, etc.) in political processes, decision making ceremonies, as well as citizen influence on the formation of political systems and institutions, their operation, drafting political decision. Several classifications of political engagement are observed: conventional and unconventional; orthodox and unorthodox, offensive; latent and evident; individual and collective; direct and indirect; acceptable active, acceptable passive, unacceptable active and unacceptable passive, and so on.

Based on logical operationalization, the toolkit for political participation types and index assessment is analyzed. Proposal is made to implement a more comprehensive and sensitive chart. Some attractive results gained after employing a survey in the RA are presented.
\end{abstract}

Keywords: political participation, political behavior, types of political participation, political institutions, political participation evaluation chart.

Ideas about democracy have been changing and evolving. Yet, the core idea has remained the same: participation of wider societal layers in the processes of governance and political decision making.

The concept of Participatory Democracy has a central role in modern theories on democracy. The idea of participatory democracy was developed by modern political theorists Carol Pateman (author of the term "participatory democracy" and the book "Participation and Democratic Theory"), Crawford Macpherson, Joseph Zimmerman, Benjamin Barber and others (see Fuchs, 2011, p. 260).
Participatory democracy supposes active involvement of citizens in discussions and decision making process in various areas of public and political life. In countries with participatory democratic system citizens are politically relevant; they are to be involved in the political system as active participants (see Almond \& Verba, 1963, p. 4).

The issue of engaging citizens in political processes was a matter of analyses even for ancient thinkers. In his work "Politics" Aristotle wrote: “... man is by nature a political animal; and the person who, by nature and not under consequences, lives beyond a state is 
either morally infantile or a superman" (Aristotle, 1983, p. 378).

Although the issues of behavior and participation were among the interest areas of researchers during the centuries to follow, namely during the new and modern eras, the notion of political participation got its academic status only in the second half of the $20^{\text {th }}$ century.

Some authors define three stages of evolution of the term "political participation": 1) study of individual aspects of political and civic participation until the mid-nineteenth century; 2) study of participation issue in the context of state governance and participation in elections within political sociology and political science $\left(19-20^{\text {th }}\right.$ centuries); 3) use of the idea "political participation" as an independent academic category in concepts of modern political science (second half of the $20^{\text {th }}$ century) (see Pfetser, 2013, p. 105).

The success of sociological research targeting assessment of political participation indices is largely conditioned by the level of development and logical analyses of notions reflecting the phenomena under consideration.

However, as M. Kholmskaya notes, in modern professional literature there is no unique and universally accepted definition of the notion "political participation."

American political scientists Gabriel Almond and Sidney Verba define political participation as a citizen activity aiming to impact directly or indirectly public administrators and their activities (see Almond \& Verba, 1992 , p. 123). Political participation is perceived as a tool through which a citizen influences the authorities, formation of institutions and their activities (Pfetser, 2013, p. 104).
G. Almond and S. Verba highlight that political participation is "first of all instrumental activeness through which citizens try to influence the government for it to act to their wish" (Vasilik, 2000, p. 213).

Thus, political participation is involvement of citizens (in the broader sense including public subjects like organizations, groups, etc.) in political processes, decision making ceremonies, as well as citizen influence on the formation of political systems and institutions, their operation, drafting political decision.

Forms and methods of political participation vary. Among them are participation in elections; active support for a candidate; participation in demonstrations and protests; organization of the latter; membership in political parties; submitting proposals, and so on.

Several classifications of the term "political participation" can be found in professional literature.

American scientist A. Marsh identifies three main types of political participation: orthodox, unorthodox and political offense. By the orthodox form of political participation he understands legal activities providing stable functioning of the political system (engagement in voting, sanctioned demonstrations and protests, actions of lobby and interest groups). Unorthodox participation is an unauthorized action (strike, boycott, civic disobedience) or that of protest against the political system. And political offence (crime), according to Marsh, denotes political activities involving violence (unauthorized demonstrations, seizure of buildings, damage to property, hostage taking, unrest, civil war, etc.) (see Vasilik, 2000, p. 214). 
Somewhat similar classification is offered also by another American analyst W. Millbright. He singles out conventional and unconventional forms of political participation. Conventional political participation is legal functioning regulated by law (involvement in elections and parties, interaction with officials, etc.). And unconventional political participation entails illegal actions denounced by major public (involvement in unsanctioned demonstrations, unrest, violence, terrorism, etc.). W. Millbright also differentiates between active and passive types of political participation based on involvement intensity, also between acceptable and unacceptable forms based on the type of involvement. Thus, Millbright identifies four groups of political participation: acceptable active; acceptable passive; unacceptable active, unacceptable passive (see Vasilik, 2000, pp. 214215).

In their article "Political Participation and Civic Engagement: Towards a New Typology", Joakim Ekman and Eric Amna offer to differentiate between latent (not evident or highlighted) and evident, individual and collective, legal and illegal forms of political participation (see Ekman \& Amna, 2012, pp. 283-300). Taking account of the considered specter of definitions of political participation and forms of that participation, it is vital to work out some scale allowing to note various manifestations and levels of participation for all the above mentioned types of political participation and activeness. From this perspective the classification of participation and activeness offered by Russian political theorist A.V. Melnik, is worth mentioning. He proposes the following types of forms and levels of participation:
1. Formed reaction towards the actions of the political system, institutions and/or their representatives;

2. Engagement in actions related to representational powers (electoral behavior);

3. Participation in political parties and non-governmental organizations;

4. Exercise of functions in institutions within the political system or acting against it;

5. Direct involvement in political actions (demonstrations, elections, petitions);

6. Active, leading activity in political movements directed against the existing political system and seeking to achieve radical changes (see Melnik, 1999, p. 345).

This chart can be completed under the criteria set for similar charts and concerning accuracy, comprehensiveness, relevant sensitivity, exactness and reliability (see Gorshkov \& Sheregi, 1990, pp. 52-55).

The following should as well be set as a precondition of integration into political and public processes: a) citizen awareness about and interest in these processes and realities; $b$ ) certain assessment of, attitude towards and approach to these processes.

Radical or non-conventional manifestations (participation in unauthorized, demonstrations, pickets, insurgencies, etc.) of political and citizen engagement should also be involved in this mode of classification. Finally, this chart should include to some extent motivated and acknowledged inertness, apathy or inactivity of citizens, often referred to as "immobile" form of political engagement. So this diagram will comprise ten characterizing features of citizen and political participation: 
1. Interest in and awareness about political processes;

2. Assessment of, attitude towards and approach to these processes;

3. Formed reaction towards the actions of the political system, institutions and/or their representatives;

4. Engagement in actions related to representational powers (electoral behavior);

5. Participation in political parties and non-governmental organizations;

6. Exercise of functions in institutions within the political system or acting against it;

7. Direct involvement in political actions (demonstrations, elections, petitions, etc.);

8. Active, leading activity in political movements and organizations;

9. Demonstrations of radical or non-conventional political engagement;

10. Acknowledged inertness, immobile participation and abstsenteizm.

The large-scale survey held by Scientific Research Center "Caucasus" in 2010 imple- menting this set of tools has revealed rather interesting outcomes.

According to the data obtained, women are less $(45,5 \%)$ interested in political goingson than men $(54,9 \%)$. On the whole women are less aware of political realities than men. Finally, women are less involved in nonconventional political engagement forms $(4,2 \%)$ than men $(8,2 \%)$. (see Hovhannisyan, Zakaryan \& Osipov 2011: 8, 56)

A major part of the respondents demonstrated significantly passive $(33,7 \%)$, sometimes inert, apathetic and immobile (16,5\%) positioning towards social-political events. Women not interested in social-political events comprise $17,5 \%$ and men $-15,3 \%$. Inertness is more observed among the young: $19,8 \%$ among people of $18-30 ; 17,8 \%$ among 31-45 age limit. (see Hovhannisyan, Zakaryan \& Osipov, 2011, p. 10).

Another major and fundamental index of political and civic activeness is participation in elections of various government levels. Survey results prove that the participation index is increasing among the public depending on the significance and importance of the elections. See Diagram 1.

Diagram 1. Respondents' engagement in elections for different levels.

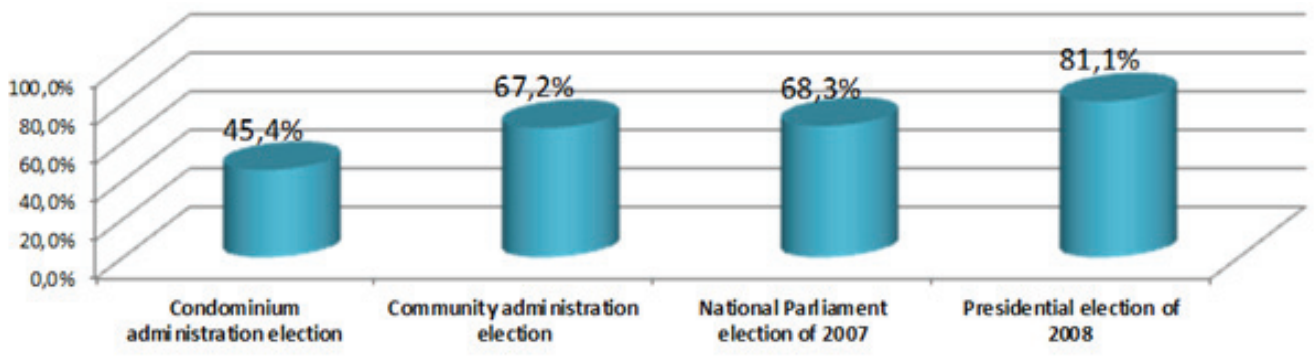

From comparative analysis of research held by various research centers (see Poghos- yan, 2006, p. 152; Hovhannisyan, Zakaryan \& Osipov, 2011, p. 14) it becomes clear that 
since 1995 there is an obvious increase in the citizen participation in political and social processes. If only $2,9 \%$ of the questioned in 1995-96 said they belonged to some political party, that number has definitely grown reaching $10,7 \%$ in 2011 . However, the number of members of non-governmental organizations has remained almost the same $-5 \%$ and 5,2\% respecttively (see Poghosyan, 2006, p. 152; Hovhannisyan, Zakaryan \& Osipov, 2011, p. 14).

Besides structural operationalization of the concept political participation in its different manifestations, it is also important to make its factorial analysis; to reveal the role and impact of such factors as the subject's gender, age, level of education, profession, marital status and social conditions, place of residence (rural or urban), membership in or support for some political organization, stereotypes of public opinion. In order to comprehend and interpret modern political processes it is desirable also to expose and analyze the motivation of involvement in politics because most profound information about any phenomenon lies in its determination, in this case in the motivation.

\section{REFERENCES}

Almond, G., \& Verba, S. (1963). The Civic Culture: Political Attitudes and Democracy in Five Nations. New York: Princeton University Press.

Almond., G., \& Verba, S. (1992). Grajdanskaya kul'tura i stabil'nost' demokratii (The Civic Culture: Political Attitudes and Democracy, in Russian). Politicheskie isledovaniya. Polis. No 4 , http://www.polisportal.ru/index.php? page $\mathrm{id}=51 \& \mathrm{id}=28$ (latest view 06.12.2016).

Aristotle. (1983). Politika (Politics, in Russian), Sochineniya v 4 T., T 4. Moscow.

Ekman, J., \& Amna, E. (2012). Political Participation and Civic Engagement: Towards a New Typology, Human Affairs, 22. DOI: 10.2478/s13374012-0024-1

http://link.springer.com/article/10.24

78/s13374-012-0024-1;

file:///C:/Users/Asus/Downloads/HA -D-12-00001[1].pdf (latest view 19.11.2016).

Fuchs, Ch. (2011). Foundations of Critical Media and Information Studies. London and New York: Routledge.

Gorshkova, M.K., \& Sheregi, F.E. (Ed.) (1990). Kak provesti sotsiologicheskoe issledovanie. (How to Conduct Sociological Study, in Russian). Moscow: Izdatel'stvo politicheskoi literatury.

Hovhannisyan, H., Zakaryan, L., \& Osipov, V. (2011). Hayastanum hasarakakan-qaghaqakan masnakcut'yan genderayin ar'and'nahatkut'yunnery' (Gender Dimension of Civic and Political Participation, in Armenia), zekuyc sociologiakan hetazotut'yan ardyunqneri veraberyal. Yerevan.

Melnik, V.A. (1999). Politologiya (Politology, in Russian), Minsk: Vyshaya shkola.

Pfetser, S.A. (2013). Teoretiko-metodologicheskie osnovaniya analiza problemy politicheskogo uchastiya (Theoretical and Methodological Bases of An- 
alyzing the Problem of Political Participation, in Russian), Vestnik $\mathrm{Ke}$ merovskogo gosudarstvennogo universiteta, No3 (55) T.1, DOI: $10.21603 /$ 2078-8975-2013-3-103-110, http://cyberleninka.ru/article/n/teoreti ko-metodologicheskie-osnovaniya- analiza-problemy-politicheskogouchastiya (last viewed 19.11.2016). Poghosyan, G.A. (2006). Hay hasarakut'yuny XXI daraskzbin (Armenian Society at the Beginning of the XXI Century). Yerevan: Lusabac.

Vasilik, M.A. (2000). Politologiya (Politology, in Russian). Moscow: Gardariki. 